\title{
Ethnobotanical knowledge and conservation practices of indigenous people of Mbeliling Forest Area, Indonesia
}

\author{
MARLINDA MULU ${ }^{1, \bullet}$, ZEPHISIUS R.E. NTELOK ${ }^{1}$, PETRUS SII ${ }^{2}$, HILDEGARDIS MULU $^{3}$ \\ ${ }^{1}$ Departement of Primary School Teacher Education, Faculty of Education, Universitas Katolik Indonesia St. Paulus Ruteng. Jl. Ahmad Yani No. 10 \\ Ruteng, Manggarai 86511, East Nusa Tenggara, Indonesia. Tel./fax.: +62-385-22305/21097, `email: lindamulu@ gmail.com \\ ${ }^{2}$ Department of Indonesian Language and Literature Education, Faculty of Education, Universitas Katolik Indonesia St. Paulus Ruteng. Jl. Ahmad Yani \\ No. 10, Ruteng, Manggarai 86511, East Nusa Tenggara, Indonesia \\ ${ }^{3}$ Department of Mathematics Education, Faculty of Education, Universitas Katolik Indonesia St. Paulus Ruteng. Jl. Ahmad Yani No. 10 Ruteng, \\ Manggarai 86511, East Nusa Tenggara, Indonesia
}

Manuscript received: 23 November 2019. Revision accepted: 9 April 2020.

\begin{abstract}
Mulu M, Ntelok ZRE, SII P, Mulu H. 2020. Ethnobotanical knowledge and conservation practices of indigenous people of Mbeliling Forest Area, Indonesia. Biodiversitas 21: 1861-1873. The indigenous people of Mbeliling Forest Area, Indonesia have long interacted with nature, in the form of utilizing forest resources for their survival. Therefore it is essential to identify the plants used to support their lives. In addition, they also have traditional institutions that manage the lives within groups. It is necessary to study the forms of environmental conservation applied by the indigenous people. This research is qualitative research with an ethnographic method and case studies. The research data is collected through observation and interviews. The data were analyzed descriptively and qualitatively. The results showed that total of 158 plant species belonging to126 genera and 64 families are used in the study area. They include 26 species used for food, 6 species for drinks, 60 species for medicine, 38 species for construction, 26 species for craft, 8 species for coloring, 6 species for cosmetics, 7 species for pesticides, and 16 species for traditional rituals. In terms of conservation, indigenous people work together with the village government. The forest area is divided into ulayat forests (communal forest) and protected forests. The management of communal forests is the right of indigenous people so that it functions as a production forest. Although communal forests are the right of indigenous people, which is managed by customary leaders, its utilization is affected by the status of protected forests established by the government. In protected forests, there are no plantations or agricultural activities.
\end{abstract}

Keywords: Conservation, ethnobotany, indigenous people, Mbeliling forest

\section{INTRODUCTION}

Indonesia has diversity of ethnicities and cultures with its local wisdom. This local wisdom refers to the traditional and unique local knowledge, which is maintained and developed by the indigenous communities through a long history of interaction with the surrounding natural environment (Sukarata 1999). Indonesia is also known as a country with extensive tropical rain forests on its islands, which are rich in biodiversity. Heyne (1987) stated that Indonesia is one of the centers of distribution of biodiversity in the world, in which there are about 25,000-30,000 species of flowering plants. Indonesian Biodiversity Strategy and Action Plan (IBSAP) data estimate that there are 38,000 plant species in Indonesia (Walujo 2011), of which about $55 \%$ are endemics. Various ethnic groups in Indonesia use this plant diversity for various purposes, such as food sources, sources of medicines, construction materials, crafts, animal feed, dyes, and also as poisons (Heyne 1987).

The Manggarai is a tribe that has inherited traditional wisdom and it also upholds the customs. The local wisdom of the community is not confined to any one aspect of life, but includes various aspects such as agriculture, health, and the environment. This inherited knowledge is useful and important for the survival of the community itself. For instance, knowledge of traditional medicine that utilizes certain types of local plants and also other activities, has an impact on economic improvement of the community (Simatupang 2018, Darlen et al. 2015).

Traditional wisdom also plays an important role in the sustainable management of natural resources. Ethnobotanical knowledge is one indicator of the sustainable use of forest resources. Declining ethnobotanical knowledge marks the beginning of forest degradation because of the declining role of local institutions in carrying out sustainable use of forests (Pei 2013, Pei 2009). Ethnobotany studies the relationship between humans and plants, not only their use but also ecological, economic, social, non-economic, and pharmaceutical elements (Martin 1995; Cotton 1996; Balick and Cox 1996; Maheshwari at al. 2018; Supiandi et al. 2019). Ethnobotany can be used as a tool to document the knowledge of traditional communities and ordinary people who have used a variety of plants to support their lives so that the plants can be managed (Bennet 2005; Suryadarma 2008).

Traditionally, indigenous people have local wisdom, which has the potential and strength needed for the management of forest areas (Nopandry 2007). Local wisdom also includes the knowledge of the use of natural resources to improve the quality of life of the community. This results in people's lives becoming very dependent on the natural environment. Their knowledge also gradually develops following the changes in people's mindsets, and the changes in the social, economic, and ecological 
environment. These kinds of changes often encourage the exploitation of natural resources, which can increase significantly (Walujo 2011).

Manggarai Tribe which has been living around the Mbeliling area has long interacted with nature, in the form of utilizing natural resources for their survival. This activity creates direct interaction between humans and plants. At the same time, this also creates community dependence on plants. The implication of the utilization process is an increase or decrease in the availability of certain types of useful plants.

One of the ancient forests in this region is the Mbeliling forest which is home to many species., Mbeliling and Sano Nggoang is a biological sanctuary with many plant species showing ancient distribution patterns (UNESCO 2009). The purpose of this study was to identify and classify plants used by the Mbeliling people for the purpose of food, medicines, building construction, crafts, cosmetics, dyes and pesticides, and other plants that are deemed sacred in certain traditional ceremonies. Furthermore, this study was also aimed to describe activities or forms of conservation practiced by traditional institutions and indigenous people in the Mbeliling area of West Mangagrai District, Nusa Tenggara Timur, Indonesia.

\section{MATERIALS AND METHODS}

\section{Study area}

This research was conducted in the three villages (ulayats), namely Tu'a Golo Roe, Tu'a Golo Culu, and
Tu'a Golo Cecer, which are around the Mbeling forest area. This tree ulayats are located in the Mbeliling Subdistrict of West Mangagrai District, Nusa Tenggara Timur Province, Indonesia. Mbeliling forest is a tropical forest covering an area of $30,412,360$ ha which consists of $7,624,083$ ha of conversion forest, 8,252,864 ha of protected forest, 13,079,183 $\mathrm{Ha}$ of limited production forest, and 1,456,230 ha of other use areas (Firdaus 2012). This forest is surrounded by 27 villages of three subdistricts. The indigenous people in these three regions are generally known as the Kempo people because they come from the Kedaluan Kempo system (the territory of an ancient kingdom). In terms of the customary governance system, each of these three regions are led by an elder called Tu'a Golo. Their dialect is a slightly different from the regional language of the Manggarai tribe.

The main livelihoods of people in these three regions are in agriculture and plantations. Traditional farming practices by growing rice and vegetables are generally used for their own consumption. Whereas for plantations, the common plants are hazelnut, cloves and coffee trees which are used as sources of income. Meanwhile, there are also people who work as craftsmen, weavers, carpenters, palm sugar and local alcoholic drinks (locally known as Tuak) producers, some work as teachers, and some work as officers in government. The Culu and Roe communities are known as producers of Tuak, while the Cecer community is known as craftsmen/weavers and eco-tourism activists because there are found several art galleries produced by non-governmental organizations (NGO) that provide traditional art performances for visiting tourists.

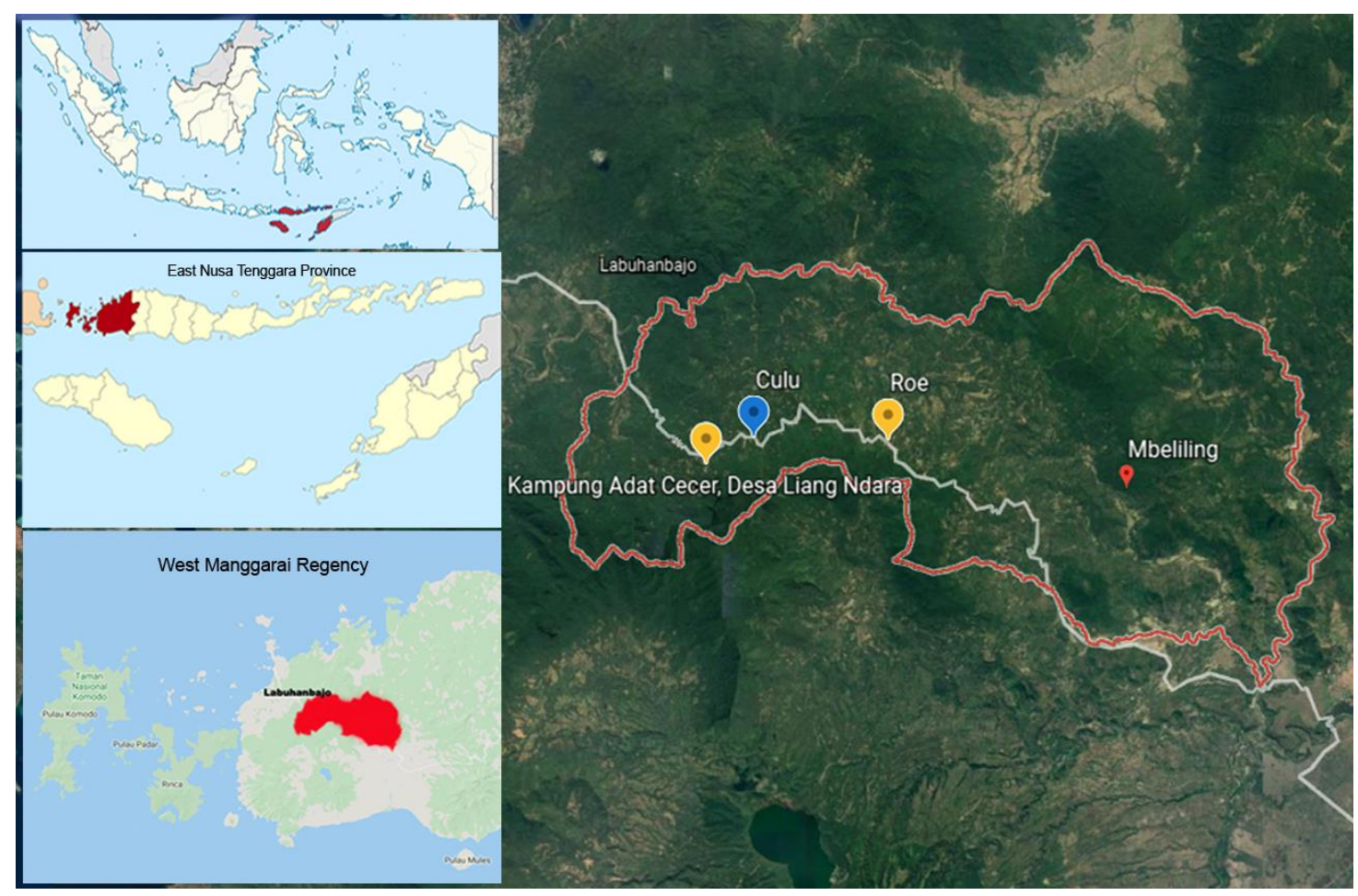

Figure 1. Map showing the study area at three ulayats in Mbeliling Sub-district, East Nusa Tenggara Province, Indonesia 


\section{Procedures}

This research used a qualitative method with an ethnographic and case study approaches, involving indepth interviews and observation of relevant individuals (Creswell 2014). Observations are carried out directly in the community environment, both in terms of social and cultural aspects regarding the use of plants around the Mbeliling forest area.

The selection of research respondents was made using purposive sampling and purposive snowball techniques. Purposive sampling is intended to select respondents based on their level of knowledge and understanding of local ethnobotany, and it is believed to represent the information to be obtained. Snowball method is the selection of respondents based on recommendations of previous respondents who have been interviewed. The subjects of this study are the customary leaders locally known as $T u^{\prime} a$ Golo and the people who have settled in the three ulayat (villages) around the forest area. A total of 30 such respondents were selected consisting of both males or females. Plant specimens were collected through exploration of the Mbeliling forest area, carried out with the help of some local residents.

\section{Data analysis}

The data were analyzed qualitatively using the interactive analysis model of Miles and Huberman (1994). This analysis model consists of three components, namely data reduction, data presentation, and drawing conclusions or verification. Data reduction is intended to summarize, choose the main and important things, and look for themes and patterns. The reduced data will give a clearer picture. The presentation of data is by writing a narrative text. Thus, it is easier to understand what is happening and plan further work based on what has been understood. After that, credible conclusions are drawn.

The plants were identified with the help of photographs and relevant botanical literature from Verheijen (1982). The botanical names of the plants were verified using the plant list (www.theplantlist.org.).

\section{RESULTS AND DISCUSSION}

\section{Ethnobotanical knowledge of Mbeliling indigenous people}

Analysis of the data indicated that a total of 158 species of plants from 126 genera and 64 families are used by the indigenous people living around the forest area, for nine different purposes (Table 1). Of them, 60 species are used as medicinal ingredients, 38 species as building materials, 26 species as food (sources of carbohydrates, vegetables, and fruit), 26 species as craft materials, 16 species in traditional rituals, 8 species for coloring/dyeing, 7 species as pesticide ingredients, and 6 species each as cosmetics and sources of drinks.

When compared to the community around the mountains in Ruteng (Iswandono et al. 2015), the ethnobotanical knowledge of the Mbeliling indigenous people is not much different. However, there are some species not found in Mbeliling but found in the Ruteng mountains and vice versa. The difference in the topography of the region is one of the causes that certain species are found in the highlands, and other species are only found in the lowlands. Besides, this difference can also be caused by traditions that passed through generations that are slightly different between these two regions, both in terms of utilization of plants as food or as medicines and others. Local botanical knowledge is essential for the survival of local communities, but there is a global trend of the loss of local botanical knowledge among the young generation, which causes serious concern among ethnobotanists (Wiryono et al. 2019).

Plants have provided the fulfillment of basic needs for humans and animals, such as food, clothing, protection, and medicine. Humans also use plants and trees for worship, rituals, ceremonies, sorcery, magic, house building, and also in the development of their socio-religious culture (Jena 2010). People from all cultures always depend on plants for their basic needs and have naturally learned the different utilization of plants (Idu 2009). This longestablished relationship directly increases people's knowledge of the use of certain plants.

\section{Food plants}

Generally, food from bigger plants can be obtained from forest products in the form of fruits, leaves, and seeds (Permana and Gunawijaya 2011). The Mbeliling community utilizes various parts of 26 species of plants, such as tubers, stems, leaf, and fruits, as food sources (Table 2). Most of these kinds of foods are obtained from the forest, some grow wild around the villagers' houses, while some others are intentionally cultivated by the people. Segregation of data based on plant parts used showed that $46.4 \%$ are fruits, $25 \%$ root tubers, $17.9 \%$ leaves, $7.14 \%$ stems, and $3.56 \%$ stem tubers.

Some forest plants are cultivated by the Mbeliling indigenous people, such as 4 varieties of Dioscorea and Pachyrhizus erosus (Figure 2.A). Nine species are used as carbohydrate sources. Meanwhile, non-cultivated vegetable sources are 6 species, and forest sources are 13 species. People process their food by soaking first, then boiling, frying, steaming, and roasting. Regarding edible fruits, all can be eaten directly.

Dioscorea spp, Arenga pinnata and Corypha utan (Figure 2.B-D) are traditional food sources for indigenous people in Mbeliling. Arenga pinnata and Corypha utan are used as sources of starch flour or sago (local: sagu), which was one of the staples in ancient times.

The indigenous people of Mbeliling distinguish between the processed products from the above two plants. Flour produced from Arenga pinnata is called "Kuwang," while from Corypha utan is called "Mbutak." Both of these traditional foods are no longer found because carbohydrate sources have been replaced by other cultivated plants. Besides that, their processing is time-consuming. However, the community still remembers the stages of its processing. The pattern of utilization of plants is related to the culture of the community. The culture of an area determines the type of food, and it's processing, and presentation (Sartika 2013). 


\section{Herbal drinks}

Mbeliling indigenous people use only 6 species as sources of herbal drinks (Table 3). One of the most commonly used species is Arenga pinnata. The sap obtained from this tree is used as the basic ingredient for making Tuak and Sopi (a traditional Manggarai drink containing alcohol). Interestingly in the process of making Tuak, the juice (Nira) is kept in a cylindrical container made of Bamboo spp. called Dongge. People usually soak the plant stems of Pterospermum diversifolium (Malvaceae) into Dongge during the tapping process (Figure 3.A-B). This soaking process is performed for the purpose of fermentation. The results show that the root of Pterospermum sp, which is added to the palm sugar sap served as a preservative of palm wine, causing the alcohol content of fermented palm sap to last longer at a concentration of $4 \%$ for 64 hours and to slow the fermentation of alcohol into acetic acid (Mentari et al. 2017).

Tuak will be stored in a container made of fruits of Lagenaria siceraria, called Bongko (Figure 3.C-D). To increase the quality of the drink, the community also soak
Peltophorum pterocarpum (Fabaceae) logs before drinking. This tree can be used as an anti-dysentery drug, medicine for swelling, and toothache medicine (Heyne 1987). These species are used as a source of drinks only when they are running out of water during exploring the forest for particular purposes. The part used is the stem of the plants.

Table 1. Number of plant species used by the Mbeliling community for various purposes

\begin{tabular}{lcc}
\hline Utilization types & $\begin{array}{c}\text { Number of } \\
\text { species }\end{array}$ & $\%$ \\
\hline Food (sources of carbohydrates, & 26 & 13.5 \\
vegetables \& fruits) & 6 & 3.1 \\
Drinks & 60 & 31.1 \\
Medicines & 26 & 13.5 \\
Crafts and household goods & 38 & 19.7 \\
Building materials & 8 & 4.1 \\
Coloring & 7 & 3.6 \\
Pesticides & 6 & 3.1 \\
Cosmetics & 16 & 8.3 \\
Traditional rituals, myth/legend &
\end{tabular}

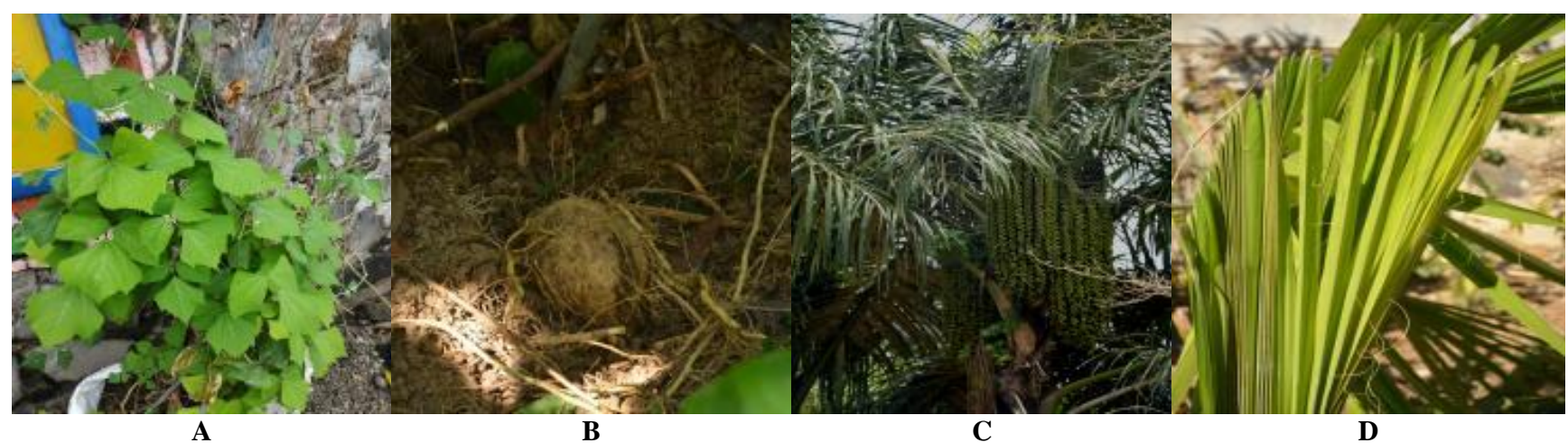

Figure 2. Plants used as food: A.Pachyrhizus erosus L., B. Arenga pinnata (Wurmb) Merr., C. Dioscorea hipsida Dennst., D. Corypha utan Lamk.

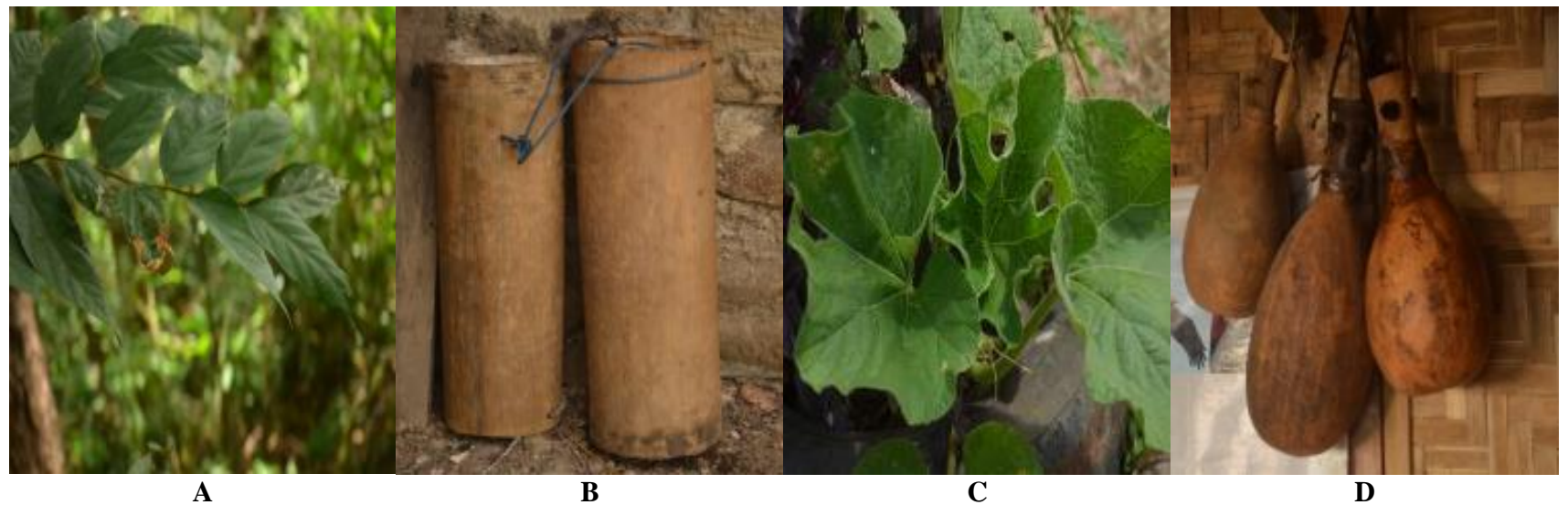

Figure 3. Plants used in the preparation of tuak. A. Pterospermum diversifolium Blume, B. Dongge is used to store sap from Arenga pinnata (Wurmb) Merr., C. Lagenaria siceraria, D. Bongko is used to store tuak 
Table 2. Wild and cultivated plants species used for food

\begin{tabular}{|c|c|c|c|c|}
\hline Scientific name & Local name & Family & Part used & Category \\
\hline Dracontomelon dao (Blanco) Merr. \& Rolfe & Sau & Anacardiaceae & Fruit & $\mathrm{W}$ \\
\hline Arenga pinnata (Wurmb) Merr. & Raping & Arecaceae & Stem, Fruit & $\mathrm{W}$ \\
\hline Corypha utan Lamk. & Cowang & Arecaceae & Stem & W \\
\hline Dioscorea hipsida Dennst. & Raut & DioscoreaceaeDioscoreaceae & Tuber & W \\
\hline Dioscorea alata $\mathrm{L}$. & Uwi & Dioscoreaceae & Tuber & $\mathrm{W}$ \\
\hline Dioscorea esculenta L. & Tese & Dioscoreaceae & Tuber & $\mathrm{C}$ \\
\hline Dioscorea sp. & Ngang & Dioscoreaceae & Tuber & $\mathrm{C}$ \\
\hline Dioscorea aculeata $\mathrm{L}$. & Cewo & Dioscoreaceae & Tuber & $\mathrm{C}$ \\
\hline Dioscorea sp. & Sengkel & Dioscoreaceae & Tuber & $\mathrm{C}$ \\
\hline Polystichum sp. & Paku & Dryopteridacea & Leaf & $\mathrm{W}$ \\
\hline Elaeocarpus floribundus Blume & Damu & Elaeocarpaceae & Fruit & W \\
\hline Pachyrhizus erosus L. & Bengkoang & Fabaceae & Bulb & $\mathrm{C}$ \\
\hline Gnetum gnemon L. & Cuka & Gnetaceae & Leaf & $\mathrm{W}$ \\
\hline Melastoma setigerum Blume & Ndusuk & Melastomataceae & Leaf, Fruit & $\mathrm{W}$ \\
\hline Ficus variegata Blume & Ara & Moraceae & Fruit & $\mathrm{W}$ \\
\hline Syzygium sp. & Lekeng & Myrtaceae & Fruit & $\mathrm{W}$ \\
\hline Syzygium polyanthum (Wight) Walp. & Mes & Myrtaceae & Fruit & $\mathrm{W}$ \\
\hline Psidium guajava L. & Jembu & Myrtaceae & Fruit & $\mathrm{C}$ \\
\hline Champereia manillensis (Blume) Merr. & Sasang & Opiliaceae & Leaf & $\mathrm{W}$ \\
\hline Passiflora foetida $\mathrm{L}$. & Anggor & Passifloraceae & Fruit & $\mathrm{W}$ \\
\hline Plantago major $\mathrm{L}$. & Sendok & Plantaginaceae & Leaf & $\mathrm{W}$ \\
\hline Sorghum saccharatum (L.) Moench & Dewas & Poaceae & Fruit & $\mathrm{W}$ \\
\hline Ardisia sp. & Rempuk & Primulaceae & Fruit & W \\
\hline Amomum sp. & Pane & Zingiberaceae & Fruit & $\mathrm{W}$ \\
\hline Amomum sp. & Pane Jarang & Zingiberaceae & Fruit & $\mathrm{W}$ \\
\hline Aтотит sp. & Pos & Zingiberaceae & Fruit & $\mathrm{W}$ \\
\hline
\end{tabular}

Note: C: Cultivated, W: Wild

Table 3. Plant species used as drinks

\begin{tabular}{llll}
\hline Scientific name & Local name & Family & Part used \\
\hline Arenga pinnata (Wurmb) Merr. & Raping & Arecaceae & Stem \\
Calamus heteracanthus Zipp. ex Blume & Wua & Arecaceae & Stem \\
Rourea minor (Gaertn.) Leenh. & Ngalo & Connaraceae & Stem \\
Tetracera fagifolia Blume & Racang & Dilleniaceae & Stem \\
Pterospermum disversifolium Blume & Damer & Malvaceae & Stem \\
Embelia sp. & Wase Keci & Myrsinaceae & Stem \\
\hline
\end{tabular}

\section{Medicines}

Medicinal plants play a vital role in the maintenance of human health throughout the world, notably in the tropics (Diame 2010). A medical tradition of a society is related to its local culture and relationship of people with their environment (Fauzi and Widodo 2019). The Mbeliling community is very famous for its traditional medicinal practices. This knowledge is passed down from generation to generation in a family. Of the 60 species of plants used as traditional medicinal ingredients, several species can be used as single herb to treat diseases, without the need to be mixed with other plants. Plant parts used in treatments include roots, stems, barks, leaves, shoots, and sap (Rahmawaty et al. 2019; Supiandi 2019). The indigenous people of Mbeliling, mostly use plant leaves as medicine with a percentage of $47.7 \%$, bark is $24.7 \%$, stem $15.4 \%$, root $7.7 \%$, fruit $1.5 \%$, tuber $1.5 \%$, and sap $1.5 \%$.

There are traditional herbal remedies (Table 4)that are mashed and used like scrubs, which is rubbed on the surface of the diseased body or known as maskers (local: Barak). Other methods used include directly applying herbal preparation to the surface of the body, drinking boiled extract, or directly eating the herbs. The villagers state that most of the medicinal plants are obtained from the area of Mount Mbeliling and only a small portion is obtained from the house yards, which are either cultivated or grow wild. Medicinal plants can be found in several places, including community lands, either planted or grown wild (Pandiangan 2019; Rahmawaty et al. 2019). It should be noted that the use of plants in medicine by traditional healers in these three regions involves different dosages, preparations, and techniques. It really depends on the individual traditional healers who handle specific diseases. Very few are found to be using only a particular type of plant in medicine. Usually, they will combine several species of medicinal plants and prepare a multi-herbal preparation to provide the healing effect. 


\section{Plants used for making crafts and household goods}

Indigenous people in Mbeliling still utilize traditional goods, tools, and crafts (Table 5), Kitchen utensils such as plates, bowls, cups, kettles, spoon, and winnowing trays are made from plants. Household materials like mats (Local: Loce), pillows (Local: Tange), and agricultural tools such as rice barns called Labak (Figure 4.C) and Lancing are also made from plant parts. Loce and Tange are made from the leaf of Pandanus tectorius (Figure 4.A-B). The basic material used for making Labak is the bark of certain tree species such as Prunus wallaceana, Artocarpus elasticus (Figure 4.D), and Bombax ceiba. Meanwhile, Lancing is made of Bambusa spp. These materials are mainly made by the craftsmen in the villages and also obtained from other areas around the villages. In terms of utilization of plant parts in such activities, $65.4 \%$ are stems, $19.3 \%$ leaf, $7.7 \%$ fruit, $3.8 \%$ cotton, and $3.8 \%$ shell.

In the process of making crafts and household materials, some go through the process of weaving, and some of them are carved into certain shapes. Nowadays, some of these materials are no more in us, so it is difficult to find them locally. In addition, the indigenous people of Mbeliling also make some handicrafts such as hats and fabric threads. However, the process of making and traditional spinning of yarn is no longer seen at present.

\section{Plants as source of construction materials}

Most of the houses of indigenous peoples in Mbeliling are still dominated by wooden materials, although some of them have been influenced by modern development. The indigenous people of Mbeliling classify houses into 3 groups, namely Sekang, Bonggok, and Sekang Riang. Sekang is the main house inhabited by the family. Bonggok (Figure 5.A) is a cottage that serves as the second house after the main house and is located on plantation/ agricultural land. Bonggok is usually used and inhabited in particular seasons, such as the planting season or harvest season. Bonggok is also used as a storage area for harvests. Sekang riang is a shack whose function is temporary and cannot be inhabited. Sekang riang (Figure 5.B) is used only when people want to watch the agricultural land or crops. In terms of construction, Bonggok and Sekang Riang are dominated by the use of plant species in almost all of its parts. Sekang, usually uses plant parts only for the walls, doors, windows, and the main pillar for the roof. Many forest species and wild plants growing around the yard are utilized in construction activities. The use of this species is in the form of house pillars, doors, windows, walls, and the roof. In the process of making the roof of a house, all the people of Mbeliling are very concerned about the selection of the wood used for the main pillar (middle pillar to support the roof). It is widely believed that only certain types of wood can be used as the material for the main pillar. This is explained further in the traditional rituals section. Stems (trunks) are the main part used for construction purposes $(87.1 \%)$, followed by leaf $(10.3 \%)$, and fibers $(2.6 \%)$. Species of plants used for construction purposes are listed in Table 6.

\section{Plants as source of cosmetics, coloring (dyes) materials and pesticides}

Mbeliling indigenous people use plants for cosmetics, coloring, and pesticide purposes. Species of plants used for each of these categories is shown in Table 7. The use of certain plant species for cosmetic purposes is still commonly practiced by Mbeliling indigenous people. Plants that are commonly used are usually associated with facial treatments that are used as masks from the Zingiberaceae family. For hair-care, the plant that is often used as Cocos nucifera from the Arecaceae family, while the other plants are mostly incidental. Albizia chinensis (Figure 6.A) is used as soap because its bark contains foam.

The use of natural dyes for coloring craft objects is also still found in Mbeliling. Fabric weavers and mats craftsmen still use several plant species to produce the desired color. Although the process of obtaining this color is not instant and requires more time, its use is still maintained. In the coloring process, usually, any part of a plant such as a stem, root, or leaf are blended first. After being mashed, it is boiled together with yarn or even Pandanus tectorius leaf that has been processed before. The community believes that the colors of natural dyes last longer than artificial dyes. In addition to using dyes, craftsmen also add a natural adhesive obtained from the Euphorbiaceae family member with the aim of maintaining a longer color quality because the colors are perfectly glued on threads or other craft items.

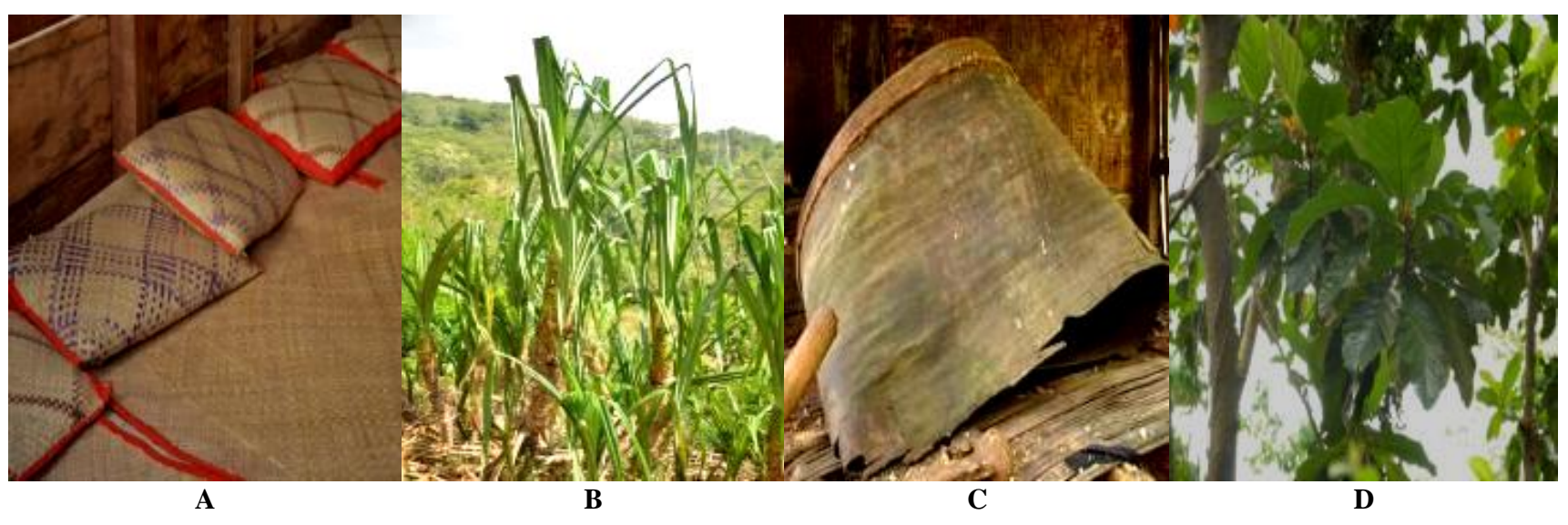

Figure 4. Household materials and plants used in their making: A. Loce and Tange colored with natural dyes, B. Pandanus tectorius Parkinson ex Du Roi, C. Labak, D. Artocarpus elasticus Reinw. ex Blume 
Table 4. Wild and cultivated plants species of plants used as medicines

\begin{tabular}{|c|c|c|c|c|}
\hline Scientific name & Local name & Family & Part used & Medicinal uses* \\
\hline Centella asiatica (L.) Urb. & Sawang & Apiaceae & Leaf & 10 \\
\hline Wrightia javanica A.DC. & Niti & Apocynaceae & Bark & 3 \\
\hline Alstonia scholaris (L.) R. Br. & Sita & Apocynaceae & Bark & 3,4 \\
\hline Arenga pinnata (Wurmb) Merr. & Raping & Arecaceae & Root & 15 \\
\hline Calamus heteracanthus Zipp. Ex Blume & Wua & Arecaceae & Root & 7 \\
\hline Areca catechu L. & Wene & Arecaceae & Root & 5 \\
\hline Blumea balsamifera (L.) DC. & Woang & Asteraceae & Leaf & 7,19 \\
\hline Eupatorium inulifolium Kunth & Sensus Rona & Asteraceae & Leaf & 5,12 \\
\hline Eupatorium odoratum L. & Sensus Wina & Asteraceae & Leaf & 5,12 \\
\hline Vernonia cinerea (L.) Less. & Mene & Asteraceae & Leaf & $5,9,10,11$ \\
\hline Ageratum conyzoides $(\mathrm{L}.) \mathrm{L}$. & Wau & Asteraceae & Leaf & $10,11,22$ \\
\hline Schefflera elliptica (Blume) Harms & Rimpa pake & Araliaceae & Leaf, stem & $5,10,11,18$ \\
\hline Heliotropium indicum $\mathrm{L}$. & Rawuk & Boraginaceae & Leaf & 3,12 \\
\hline Ananas comosus (L.) Merr. & Pandang & Bromeliaceae & Leaf & $4,7,14$ \\
\hline Canarium asperum Benth. & Pu'u Keci & Burseraceae & Bark & 21 \\
\hline Garuga floribunda Decne. & Mondo & Burseraceae & Bark & $4,5,19,21$ \\
\hline Ipomea sp. & Sara & Convolvulaceae & Leaf & 12 \\
\hline Merremia vitofolia (Burm.f.) Hallier f. & Wojang & Convolvulaceae & Leaf & 4,9 \\
\hline Momordica charantia $\mathrm{L}$. & Rea & Cucurbitaceae & Leaf & 22 \\
\hline Dillenia pentagyna Roxb. & Konang & Dilleneaceae & Bark & 22 \\
\hline Tetracera fagifolia Blume & Racang & Dilleniaceae & Stem & $4,5,19,21$ \\
\hline Jatropha curcas L. & Pandut & Euphorbiaceae & Leaf & 5 \\
\hline Aleurites moluccanna (L.) Willd. & Welu & Euphorbiaceae & Root & 4,21 \\
\hline Mallotus philipinensis (Lam.) Murll.Arg & Poser & Euphorbiaceae & Bark & 4,21 \\
\hline Cassia fistula $\mathrm{L}$. & Lembur & Fabaceae & Stem & $4,5,19,21$ \\
\hline Piliostigma malabaricum (Roxb.) Benth. & Daleng & Fabaceae & Bark & 4,14 \\
\hline Peltophorum pterocarpum (DC.) K. Heyne & Soga & Fabaceae & Bark & 5 \\
\hline Derris sp. & Porak & Fabaceae & Stem, leaf & 19 \\
\hline Bauhinia sp. & Weda & Fabaceae & Stem & 7,21 \\
\hline Pterocarpus indicus Willd. & Nara & Fabaceae & Bark & 4,21 \\
\hline Centrosema pubescens Benth. & Wue & Fabaceae & Leaf & 12 \\
\hline Persea americana Mill. & Advokat & Lauraceae & Leaf & $4,7,14$ \\
\hline Litsea sp. & Dempol Puar & Lauraceae & Leaf & $10,11,21$ \\
\hline $\begin{array}{l}\text { Cinnamomum burmannii (Nees \& } \\
\text { Blume }\end{array}$ & Ndingar & Lauraceae & Bark & 5,22 \\
\hline Cryptocarya triplinervis $\mathrm{R} \cdot \mathrm{Br}$ & Du’ul & Lauraceae & Bark & 5 \\
\hline Actinodaphne sp. & Pajung & Lauraceae & Leaf & $4,10,11,21$ \\
\hline Plectranthus teysmannii Miq. & Rengau & Lamiaceae & Stem & 3,4 \\
\hline Hyptis rhomboidea M.Martens \& Galeotti & Bontang & Lamiaceae & Leaf & $9,10,11$ \\
\hline Vitex trifolia $\mathrm{L}$. & Wora & Lamiaceae & Leaf & 19 \\
\hline Lagerstroemia flos-reginae Retz. & Munting & Lythraceae & Bark & 4,21 \\
\hline Hibiscus rosa-sinensis $\mathrm{L}$ & Kembang sepatu & Malvaceae & Leaf & 21 \\
\hline Sida acuta Burm.f. & Menangis & Malvaceae & Leaf, stem & 21 \\
\hline Swietenia mahagoni (L.) Jacq. & Mahoni & Meliaceae & Fruit & 3,4 \\
\hline Ficus septica Burm.f. & Kowong & Moraceae & Leaf & 5 \\
\hline Ficus sur Forssk. & Ara labe & Moraceae & Leaf & $5,6,9,10,11,12,14$ \\
\hline Musa acuminata Colla & Muku mada & Musaceae & Leaf & $4,7,14,19$ \\
\hline Syzygium sp. & Lekeng & Myrtaceae & Bark & $4,5,19,21$ \\
\hline Psidium guajava $\mathrm{L}$. & Jembu & Myrtaceae & Leaf & 5 \\
\hline Embelia sp. & Wase Keci & Myrsinaceae & Stem & 21 \\
\hline Oxalis corniculata $\mathrm{L}$. & Mela & Oxalidaceae & Leaf & 12 \\
\hline Fraxinus griffithi C.B.Clarke & Lui & Oleaceae & Bark, stem & $4,5,19,21$ \\
\hline Piper betle sp & Mingi (Kala wua) & Piperaceae & Leaf & $4,7,14$ \\
\hline Piper umbellatum $\mathrm{L}$. & Kutang kode & Piperaceae & Leaf & 3,4 \\
\hline Pittosporum mollucanum Miq. & Telo Acu & Pittosporaceae & Root & 4,17 \\
\hline Rubus moluccanus L. & Conco & Rosaceae & Leaf & 3,4 \\
\hline Myrmecodia sp. & Sarang semut & Rubiaceae & Tuber & 4,17 \\
\hline Allophylus cobbe (L.) Raeusch. & Lamas & Sapindaceae & Bark & 21 \\
\hline Viscum ovalifolium DC. & Tai Tala & Santalaceae & Leaf, stem & 21 \\
\hline Picrasma javanica Blume & Pa'it & Simaroubaceae & Bark & 3 \\
\hline Urticaceae sp & Lodong & Urticaceae & Sap & 21 \\
\hline
\end{tabular}

Note: *The use of plants as medicine (adapted using the level 2 ailment category by Cook (Susanti et al. 2019): 1. unspecified medicinal disorder 2. Abnormalities 3. blood system disorder 4. circulatory system disorder 5. Digestive system disorder 6. endocrine system disorder 7. genitourinary system disorder 8. ill-defined symptoms 9. immune system disorder, 10. infections/infestations 11. Inflammation 12. Injuries 13. mental disorder 14. metabolic system disorder 15. muscular-skeletal system disorder 16. Neoplasms 17. nervous system disorder 18. nutritional disorder, 19. pain 20. Poisonings 21. pregnancy/birth/puerperium 22. respiratory system disorder, 23. sensory system disorder 24. skin/subcutaneous cellular tissue disorder 25. Veterinary 26. cultural/repellent 
Table 5. Plants species used for making crafts and household materials

\begin{tabular}{|c|c|c|c|}
\hline Scientific name & Local name & Family & Part used \\
\hline Cocos nucifera L. & Nio & Arecaceae & Shell \\
\hline Corypha utan Lamk. & Cowang & Arecaceae & Leaf \\
\hline Arenga pinnata (Wurmb) Merr. & Raping & Arecaceae & Leaf \\
\hline Calamus heteracanthus Zipp. ex Blume & Wua & Arecaceae & Stem \\
\hline Agave sisalana Perrine & Pandang Lewe & Asparagaceae & Leaf \\
\hline Wrightia pubescens $\mathrm{R} . \mathrm{Br}$ & Niti & Apocynaceae & Stem \\
\hline Crescentia cujete L. & Bila & Bignoniaceae & Fruit \\
\hline Lagenaria siceraria (Molina) Standl & Cewak & Cucurbitaceae & Fruit \\
\hline Tetracera fagifolia Blume & Racang & Dilleniaceae & Leaf \\
\hline Peltophorum pterocarpum (DC.) K. Heyne & Soga & Fabaceae & Stem \\
\hline Flagellaria indica $\mathrm{L}$. & Kuar & Flagellariaceae & Stem \\
\hline Litsea sp. & Dempol puar & Lauraceae & Stem \\
\hline Lygodium circinnatum (Burm.f.) Sw & Werek & Lygodiaceae & Stem \\
\hline Artocarpus elasticus Reinw. ex Blume & Lale & Magnoliopsida & Stem \\
\hline Pterospermum diversifolium $\mathrm{Bl}$. & Damer & Malvaceae & Stem \\
\hline Gossypium arboreum L. & Kampas & Malvaceae & Cotton \\
\hline Psidium guajava $\mathrm{L}$. & Jembu & Myrtaceae & Stem \\
\hline Freycinetia scandens Gaudich. & Wewu & Pandanaceae & Stem \\
\hline Pandanus tectorius Parkinson ex Du Roi & Re’a & Pandanaceae & Leaf \\
\hline Schizostachyum blumei Nees & Helung & Poaceae & Stem \\
\hline Schizostachyum brachycladum Kurz & Belang & Poaceae & Stem \\
\hline Gigantochloa atter (Hassk.) Kurz & Gurung & Poaceae & Stem \\
\hline Prunus wallaceana Kalkman & Sema & Rosaceae & Stem \\
\hline Uncaria $\mathrm{sp}$. & Kewe rua & Rubiaceae & Stem \\
\hline
\end{tabular}

Table 6. Plants species used as sources of construction materials

\begin{tabular}{|c|c|c|c|}
\hline Scientific name & Local name & Family & Part used \\
\hline Dracontomelon dao (Blanco) Merr. \& Rolfe & Sau & Anacardiaceae & Stem \\
\hline Tabernaemontana macrocarpa Jack & Pasa & Apocynaceae & Stem \\
\hline Cocos nucifera L. & Nio & Arecaceae & Stem, Leaf \\
\hline Areca catechu L. & Wene & Arecaceae & Leaf \\
\hline Calamus heteracanthus Zipp. Ex Blume & Wua & Arecaceae & Stem \\
\hline Pinanga coronata Blume & Pinggong & Arecaceae & Leaf \\
\hline Arenga pinnata (Wurmb) Merr. & Raping & Arecaceae & Fibers \\
\hline Septogarcinia sumbawaensis Kosterm. & Sirek & Clusiaceae & Stem \\
\hline Calophyllum soulattri Burm.f. & Torang & Clusiaceae & Stem \\
\hline Garcinia dulcis (Roxb.) Kurz & Ngampur & Clusiaceae & Stem \\
\hline Dyospiros sp. & Ojang & Ebenaceae & Stem \\
\hline Elaeocarpus floribundus Blume & Damu & Elaecarpaceae & Stem \\
\hline Planchonella firma (Miq.) Dubard & Natu & Ericaceae & Stem \\
\hline Albizia chinensis (Osbeck) Merr. & Waek & Fabaceae & Stem \\
\hline Pterocarpus indicus Willd. & Nara & Fabaceae & Stem \\
\hline Peltophorum pterocarpum (DC.) K. Heyne & Soga & Fabaceae & Stem \\
\hline Cryptocarya triplinervis $\mathrm{R} . \mathrm{Br}$ & Dul & Lauraceae & Stem \\
\hline Planchonia valida Blume & Ngancar & Lechythidaceae & Stem \\
\hline Lagerstroemia flosreginae Retz. & Munting & Lythraceae & Stem \\
\hline Pterospermum diversifolium $\mathrm{Bl}$. & Damer & Malvaceae & Stem \\
\hline Dysoxylum cauliflorum Hiern & Muku Te'e & Meliaceae & Stem \\
\hline Artocarpus heterophyllus Lam. & Mok & Moraceae & Stem \\
\hline Artocarpus elasticus Reinw. ex Blume & Lale & Moraceae & Stem \\
\hline Decaspermum triflorum A.J.Scott & Puing & Myrtaceae & Stem \\
\hline Fraxinus griffithi & Mbaceng (Lui) & Oleaceae & Stem \\
\hline Swietenia mahagoni (L.) Jacq. & Mahoni & Oleaceae & Stem \\
\hline Gigantochloa atter (Hassk.) Kurz & Gurung & Poaceae & Stem \\
\hline Dendrocalamus asper (Schult.) Backer & Betong & Poaceae & Stem \\
\hline Gigantochloa Verticillata (Willd.) Munro & Pering & Poaceae & Stem \\
\hline Imperata cylindrica $\mathrm{L}$. & Satar/Ri'i & Poaceae & Leaf \\
\hline Podocarpus blumei Endl. & Tilu tuna & Podocarpaceae & Stem \\
\hline Podocarpus amarus Blume & Pinis & Podocarpaceae & Stem \\
\hline Anthocephalus cadamba (Roxb.) Miq. & Kawak & Rubiaceae & Stem \\
\hline Neonauclea sp. & Pante kraeng & Rubiaceae & Stem \\
\hline Neonauclea sp. & Pante biasa & Rubiaceae & Stem \\
\hline Acronychia trifoliata Zoll. \& Moritzi & Aseng & Rutaceae & Stem \\
\hline Elatostachys sp. & Maras & Sapindaceae & Stem \\
\hline Stemonurus celebicus Valeton & Kodal & Stemonuraceae & Stem \\
\hline
\end{tabular}


Table 7. Plant species used as cosmetics, coloring agents, and pesticides

\begin{tabular}{|c|c|c|c|c|}
\hline Scientific name & Local name & Family & Part used & Function \\
\hline \multicolumn{5}{|l|}{ Cosmetics } \\
\hline Cocos nucifera $\mathrm{L}$. & Nio & Arecaceae & Fruit & $\mathrm{H}$ \\
\hline Erythrina orientalis (L.) Merr. & Kalo & Fabaceae & Leaf & $\mathrm{S}$ \\
\hline Albizia chinensis (Osbeck) Merr. & Waek & Fabaceae & Bark & $\mathrm{Bc}, \mathrm{H}$ \\
\hline Zanthoxylum ovalifolium Tutcher & Nderu celang & Rutaceae & Fruit & $\mathrm{H}$ \\
\hline Kaempferia galanga $\mathrm{L}$. & Jangkur & Zingiberaceae & Tuber & $\mathrm{S}$ \\
\hline Curcuma zanthorrhiza Roxb. & Tewoa & Zingiberaceae & Tuber & $S$ \\
\hline \multicolumn{5}{|l|}{ Colouring agents (dyes) } \\
\hline Mangifera indica $\mathrm{L}$. & $\mathrm{Pau}$ & Anacardiaceae & Root, bark, leaf & $\mathrm{G}$ \\
\hline Pterocarpus indicus Willd. & Pateng nara & Fabaceae & Stem & $\mathrm{R}$ \\
\hline Caesalpinia sappan $\mathrm{L}$. & Pateng cepang & Fabaceae & Stem & $\mathrm{R}$ \\
\hline Cassia fistula $\mathrm{L}$ & Pateng lembur & Fabaceae & Stem & $\mathrm{Y}$ \\
\hline Tectona grandis L.f. & Jati & Lamiaceae & Stem & $\mathrm{C}$ \\
\hline Glochidion perakense Hook.f & Ngantol & Phyllanthaceae & Stem & B \\
\hline Jatropha curcas L. & Pandut & Euphorbiaceae & Sap & Imc \\
\hline Jatropha gossypiifolia $\mathrm{L}$. & Pandut laka & Euphorbiaceae & Sap & Imc \\
\hline \multicolumn{5}{|l|}{ Pesticides } \\
\hline Acorus calamus L. & Jengok & Acoraceae & Tuber & Wlp \\
\hline Crescentia cujete $\mathrm{L}$. & Bila & Bignoniaceae & Fruit & Wlp \\
\hline Gliricidia sepium (Jacq.) Walp. & Gamal & Fabaceae & Leaf & Wlp \\
\hline Planchonia valida Blume & Ngancar & Lechythidaceae & Stem & Wlp \\
\hline Dysoxylum alliaceum Blume & Ndarap & Meliaceae & Stem & Wlp \\
\hline Melia azedarach $\mathrm{L}$. & Peca mera & Meliaceae & Leaf & Wlp \\
\hline Musa acuminata Colla & Muku mada & Musaceae & Leaf & Wlp \\
\hline
\end{tabular}

Note: Cosmetics, S: skin, BC; Body care, H: Hair; Dyes, B: Black, R: Red, Y: Yellow, C: Crem, G: Green, Imc: ingredient for making colors Pesticide, WLP: White lice pest

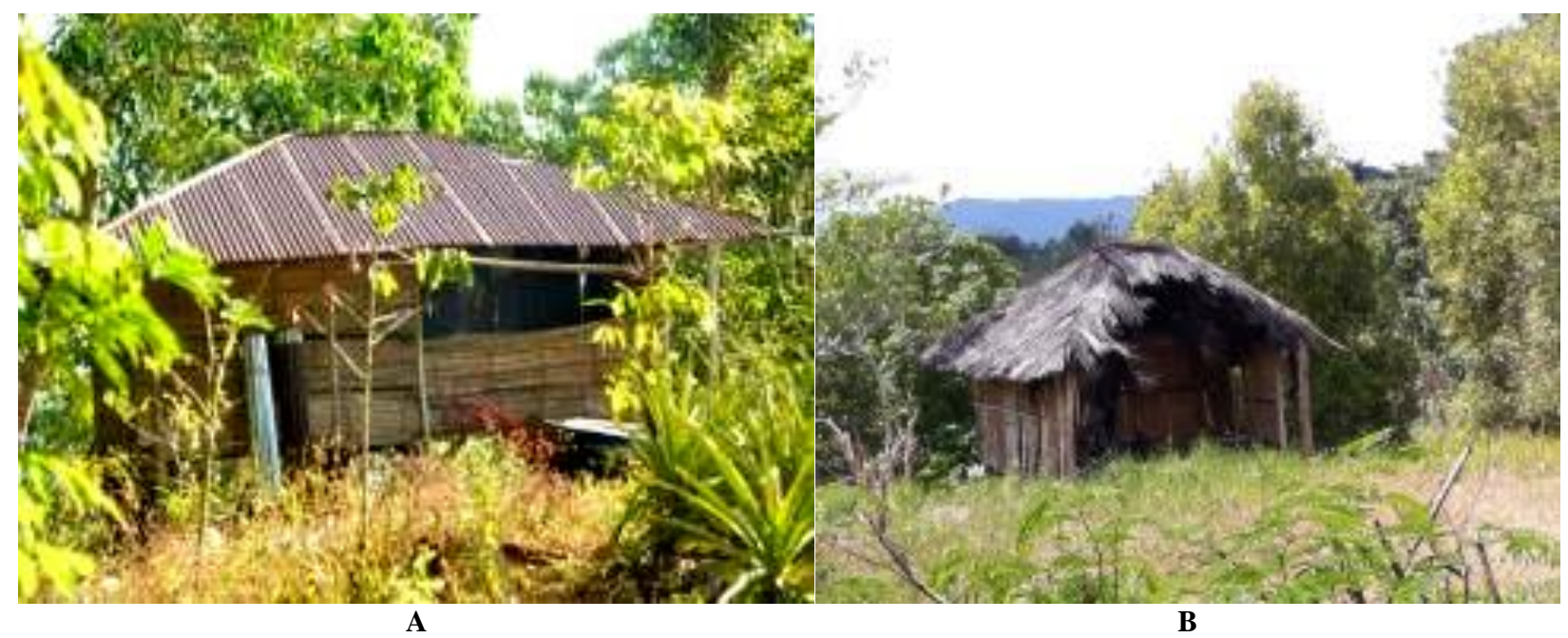

Figure 5. Traditional constructions. A. Bonggok, B. Sekang Riang

In addition to using plants for these needs, the people of Mbeliling have also practiced the use of natural pesticides in their plantations or agricultural lands. Interestingly, there are several types of plants such as Gliricidia sepium and Musa acuminata (Figure 6.B-C), which are used as pesticides without the need to mix other ingredients. The leaves of both plants are either sown or planted in agricultural land. The use of these plants is mainly to avoid white lice pests.
The phytochemical test results of Musa acuminata show this plant contains active ingredients, such as flavonoids, alkaloids, tannins, saponins, and triterpenoid., Gliricidia sepium leaf extract contains steroids, tannins, and saponins. The active ingredients present in these plants are potential plant-based pesticides because they can decrease short-term plant pest insects and disease incidence (Lumowa 2017; Lumowa 2018). The plant parts used by the community to produce pesticides varies from leaf, stems, and tubers, to fruits. 


\section{Plants in traditional rituals and beliefs}

The Mbeliling indigenous people still maintain the customs and culture of their ancestors. This tradition can be seen through life practices such as building houses, land clearing, and land distribution, harvest thanks giving, birth events, marriages, and even death processions. Almost all important traditional rituals carried out involve the use of certain plant species, and their presence is crucial. Several species of plants from the Piperaceae and Arecaceae family can be found in almost all types of traditional rituals. Mainly, the plant parts used are leaves, which accounted for $38.8 \%$, followed by $33.3 \%$ stem, $16.7 \%$ fruits, $5.6 \%$ roots, and $5.6 \%$ bark. Plants used for ritual purposes are listed in Table 8. In terms of home construction, the choice of wood as the main pillar on the roof of the house, locally called Nok, has its own philosophical aspect. The wood used must be a hardwood plant that also produces fruit. The Mbeliling community believes that woody plant that can produce fruits will also affect the fortune of the homeowner. Two species that are often used by the community for this purpose are Tabernaemontana macrocarpa and Artocarpus heterophyllus (Figure 7.A-B). In the ritual of land clearing or land distribution amongst families, Mbeliling people use Haju Pasa (Tabernaemontana macrocarpa).

In Ulayat Tu'a Golo Culu and Tu'a Golo Roe, plants are also used in the burial procession, that is during the process of digging graves. The plant used is Saccharum spontaneum (Figure 7.C). This species is used to hit the ground surface while saying a prayer sentence (local: Torok). This procession is performed before beginning the digging process. The community believes that with the beating of the ground with this plant, the stones that may be in the ground will shift so that the digging process runs smoothly. This tradition is still continued in the study area.

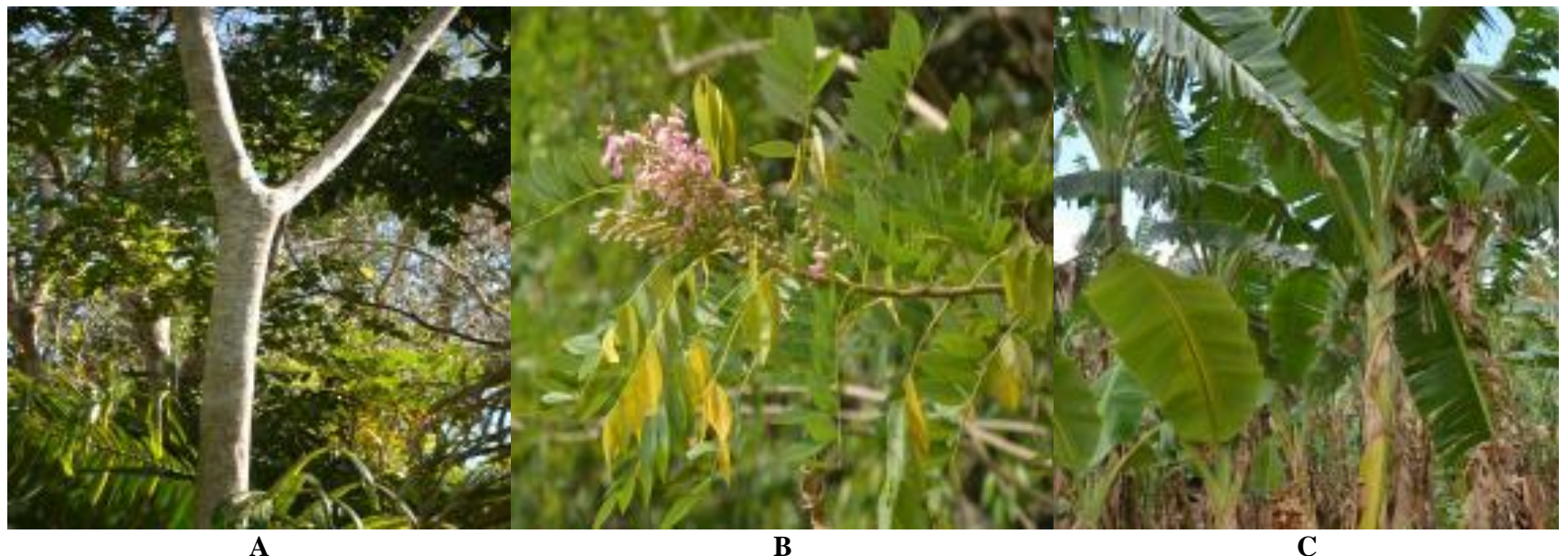

Figure 6. Cosmetic and pesticidal plants: A. Albizia chinensis (Osbeck) Merr., B. Gliricidia sepium (Jacq.) Walp., C. Musa acuminata Colla

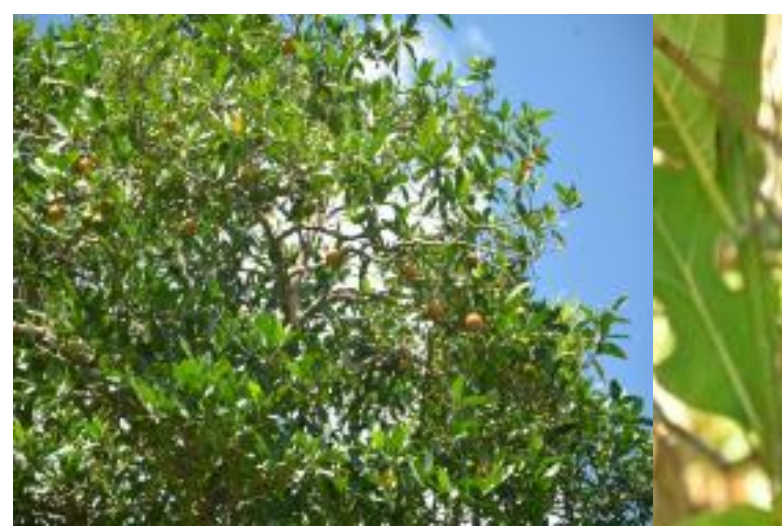

A

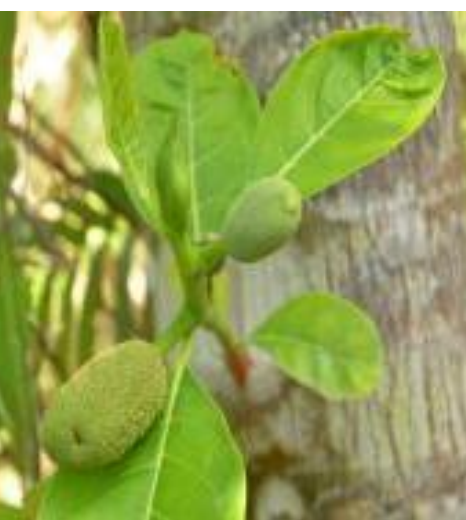

B

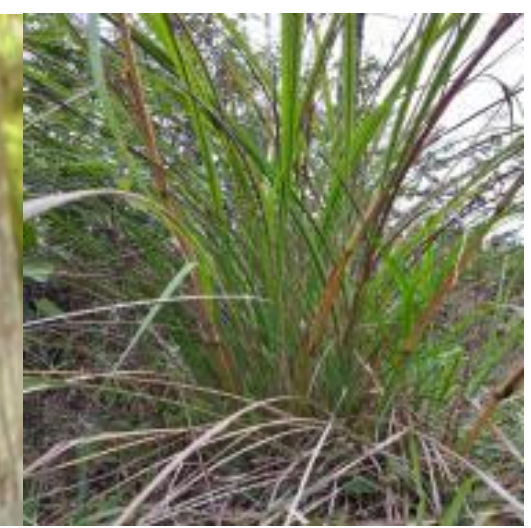

C

Figure 7. Plants used in rituals: A. Tabernaemontana macrocarpa Jack, B. Artocarpus heterophyllus Lam., C. Saccharum spontaneum L. 
Table 8. Plants species used for rituals

\begin{tabular}{|c|c|c|c|}
\hline Scientific name & Local name & Family & Part used \\
\hline Justicia gendarussa Burm.f. & Prempas & Acanthaceae & Leaf \\
\hline Tabernaemontana macrocarpa Jack & Pasa & Apocynaceae & Stem \\
\hline Calotropis gigantea (L.) Dryand. & Kole & Apocynaceae & Leaf \\
\hline Areca catechu $\mathrm{L}$. & Wene & Arecaceae & Fruit \\
\hline Cocos nucifera $\mathrm{L}$. & Nio & Arecaceae & Fruit \\
\hline Borassus flabellifer $\mathrm{L}$. & Ta’al & Arecaceae & Leaf \\
\hline Drynaria cordata (L.) Willd. Ex Schult. & Ngelong & Caryophyllaceae & Leaf \\
\hline Sida acuta Burm.f. & Menangis rapu & Malvaceae & Stem, leaf \\
\hline Artocarpus heterophyllus Lam. & Nangga & Moraceae & Stem \\
\hline Musa acuminata Colla & Muku mada & Musaceae & Leaf \\
\hline Piper betle $\mathrm{L}$. & Kala & Piperaceae & Leaf, fruit \\
\hline Pittosporum mollucanum Miq. & Telo acu & Pittosporaceae & Root \\
\hline Schizostachyum blumei Nees & Helung & Poaceae & Bark \\
\hline Saccharum spontaneum L. & Waka & Poaceae & Stem \\
\hline Aquilaria filaria (Oken) Merr. & Cue & Thymelaeaceae & Stem \\
\hline Leea indica (Burm.f.) Merr. & Mali & Vitaceae & Stem \\
\hline
\end{tabular}

\section{Conservation of Mbeliling Forest Area}

\section{The role of traditional institutions}

Culture consists of concepts about everything that is valued by and important for a community, which provides a direction for people's lives (Mukhtaromi et al. 2015). The customary institutions (in this case, the leaders) have a very important role in the life of the Mbeliling community. The authority of customary institutions in regulating communities in Mbeliling may not be written in a document. However, these unwritten rules are abode by all the members of the groups. All kinds of traditional rituals in the villages around Mbeliling forest are arranged and managed by the traditional leaders (Tu'a-tu'a Golo).

In terms of environmental conservation, the Mbeliling community highly values harmony with nature as a place to live. This can be seen from the land acquisition/distribution ceremony, harvest thanks-giving, and other processions. The Mbeliling community classifies the land into two types, namely Lingko and Puar. The term Lingko is identical to the agricultural or plantation area, whereas the term Puar covers the areas that are not agricultural or plantation lands whose management is controlled by Tu'a Golo (Firdaus 2012). Hence, all types of activities carried out in Puar are also under the supervision of customary institutions. Puar is also synonymous with wilderness areas. McNeely and MacKinnon (1990) agreed that local people and protected area managers from the government could become allies in managing a natural reserve area. While managers can learn much about resource conservation and its use, on the other hand, nature conservation supports the survival of traditional cultures.

\section{The synergy between traditional institutions and village government}

The existence of traditional institutions does not become an obstacle for the government in carrying out conservation activities. Because these two institutions have the same goal, which is to conserve the environment. Mbeliling forest was designated as a protected forest, production forest, and conservation forest in 1987. Even though the status has changed, the community can still use the forest (Firdaus 2012). Mbeliling forest area is divided into two parts, namely protection forest (Indonesian: Hutan Lindung) and customary forest ( ulayat forest). Protected forests are entirely under the authority of the government whereas, in ulayat forests, the rights of citizens and traditional institutions are protected. In this area, the indigenous people usually do agricultural activities and have a plantation area. The protected and customary forests are separated from a border, made of the stacks of forest rocks named Phase Alternation Line, or usually known as PAL Belanda (Netherland's PAL) because it was constructed during the colonial era. This border proves that the conservation of the Mbeliling forest has been established for decades. In a recent development, the area of protected forest is enlarged, which results in a decrease of the ulayat forest. This indicates the seriousness and commitment of the government and customary institutions in conserving the forest. Interviews with the traditional leaders confirm the willingness of the indigenous people to adhere to this new rule. Further, interviews also reveal how these people agree with the government because keeping the forests is equivalent to the act of preserving resources for their lives. They are also well aware of the status of the Mbeliling forest as a protected forest.

Even though customary forests are the rights of customary institutions and its people, this does not mean that management is arbitrary. The community also continues to obey the regulation stating that every felling trees/ tree cutting activities (logging activities) in the customary forest must be first informed to the village government and Tu'a Golo. In other words, the individuals must first receive a logging activity permit through a formal document named Surat Pemberitahuan Penebangan (Indonesian - SP3) or Logging Notice. Besides that, another agreement that must be obeyed in the context of conservation is that every tree that is cut must be replaced by planting a new sapling. This means that the customary 
forests still have conservation status. There has not been any protest of the indigenous people regarding this regulation. This shows well-established cooperation and collaboration between both institutions. This collaboration develops through negotiations, amalgamations, and consolidations at the interface between local and 'outsiders' interpretations of the roles and functions of leadership in a particular governance context (Steenbergen 2016).

The synergy between customary institutions and the village government is also apparent in Cecer Village. In Cecer Village, for example, an agreement was made between the Liang Ndara village government and the indigenous community, which later yields an agreement named the Village Nature Conservation Agreement) document or KPAD (Kesepakatan Pelestarian Alam Desa. The KPAD regulates all the use of resources (water, tourism assets, and food security) in the village so that the potential for damage to nature can be minimized. In the case of the utilization of forest products as a source of food, medicine, drinks, and others, the community is given almost unlimited permission to use provided that they do not cut down the trees. This is done for the purpose of conservation of the Mbeliling forest area, including its animals and plant species. Therefore, forest sustainability is maintained because species diversity and richness status in the ecosystem is important in confronting environmental threats and is guidance in plant management (Hasanpori et al. 2019). Collaboration between traditional institutions and the government in Mbeliling can suppress illegal logging that occurs so that the conservation of forest resources can be maintained properly.

It can be concluded that indigenous people in the Mbeliling forest area have considerable ethnobotanical knowledge. This is evident from the high number of plants used to support their lives, which is 158 species. These plants are used as sources of food, medicine, crafts, and others and also used in traditional rituals. The highest percentage of use was for medicines, $31.1 \%$, and the lowest was for drinks and cosmetics with a percentage of $3.1 \%$ each. In addition to utilizing plants for their daily needs, the Mbeliling indigenous people are also familiar with the conservation system. Although the community has its own leaders in the concept of customary institutions, they also comply with the government in implementing the established conservation rules.

\section{ACKNOWLEDGEMENTS}

Our gratitude goes to the Director-General of Higher Education, Indonesian Ministry of Research, Technology, and Higher Education for funding this research. We also thank the Villagers, especially Edu and Feryanto, for their assistance during fieldwork.

\section{REFERENCES}

Balick MJ, Cox PA. 1996. Plants, People, and Culture: The science of ethnobotany. Scientific American Library, New York.
Cotton, C.M. 1996. Ethnobotany: principles and applications. Wiley, Chichester.

Creswell JW. 2014. Research design: Pendekatan Kualitatif, Kuantitatif dan Mixed. Pustaka Pelajar, Yogyakarta. [Indonesian]

Darlen MF, Hadi S, Ardiansyah M. 2015. Pengembangan wilayah berbasis potensi unggulan kabupaten Manggarai Timur Provinsi NTT sebagai daerah otonom baru. Tata Loka 17: 37-52. [Indonesian]

Diame GA. 2010. Ethnobotany and ecological studies of plants used for reproductive health: A case study at a biosphere reserve in the Western Region of Ghana. UNESCO (MAB) Young Scientists Research Award.

Fauzi, Widodo H. 2019. Short communication: Plants used as aphrodisiacs by the Dayak ethnic groups in Central Kalimantan, Indonesia. Biodiversitas 20: 1859-1865.

Firdaus. 2012. Puar cama untuk anak cucu: kearifan lokal untuk sustainability forest di Manggarai Barat . Jurnal Ilmu Sosial Mamangan 1: 39-50. [Indonesian]

Hasanpori R, Sepehry A, Barani H. 2019. Rangeland conversion to dryland and its effects on species diversity and richness. Biodiversitas 20: 2043-2047.

Heyne K. 1987. Tumbuhan Berguna Indonesia, Jilid III, diterjemahkan oleh Badan Litbang Kehutanan, Yayasan Sarana Wana Jaya, Jakarta.

Idu MD. 2009.Current trends in ethnobotany. Trop J Pharm Res 8: 295296.

Iswandono E, Zuhud, EAM, Hikmat A, Kosmaryandi N. 2015. Pengetahuan etnobotani suku Manggarai dan implikasinya terhadap pemanfaatan tumbuhan hutan di pegunungan Ruteng. Jurnal Ilmu Pertanian Indonesia (JIPI) 20: 171-181. [Indonesian]

Jena, MK. 2010. A Study of Ethnobotany in Relation to the Social and Cultural Life of Certain Selected Tribes of Orissa. [Dissertation]. Faculty of Science, Uthkal University, Bhubaneswar.

Lumowa SVT, Bardin S. 2018. Uji fitokimia kulit pisang kepok (Musa paradisiaca L.) Bahan alam sebagai pestisida nabati berpotensi menekan serangan serangga hama tanaman umur pendek. Jurnal Sains dan Kesehatan 1: 465-469. [Indonesian]

Lumowa SVT, Rambitan VM. 2017. Analisis kandungan kimia daun gamal (Gliricidia sepium) dan kulit buah nanas (Ananas comosus L) sebagai bahan baku pestisida nabati. Prosiding Seminar Kimia, [S.1.], p. $170-175$, dec. 2017. (Indonesian)

Maheshwari S, Tomar SS, Sharma A. 2018. A study of ethnobotanical knowledge of tribal plants: a review of decade. Intl J Adv Sci Res Manag 1: 2455-6378.

Martin GJ. 1995. Ethnobotany: A Methods Manual. Chapman and Hall. London.

McNeely JA, MacKinnon JR. 1990. Protected areas, development, and land use in the tropics. Resour Manag Optimization 7: 191-208.

Mentari SN, Djangi MJ, Sudding. 2017. The Role of wood root bayur (Pterospermum sp.) toward sugar palm nira fermentation (Arenga pinnata). Jurnal Chemica 18: 90-95.

Miles MB, Hubermen AM. 1994. Qualitative Data Analysis: An Expanded Sourcebook. 2nd ed. Sage Publications, Thousand Oaks, CA

Mukhtaromi A, Soeaidy MS, Hayat A., et al. 2015. Sinergi pemerintah daerah dan lembaga adat dalam melaksanakan pelestarian kebudayaan. Jurnal Administrasi Publik (JAP), 1: 155-163. [Indonesian]

Nopandry, B. 2007. Hutan untuk masyarakat pemanfaatan lestari hutan konservasi. Buletin Konservasi Alam 7: 4-8 [Indonesian]

Pandiangan D, Silalahi M, Dapas F, Kandou F. 2019. Diversity of medicinal plants and their uses by the Sanger tribe of Sangihe Islands, North Sulawesi, Indonesia. Biodiversitas 20: 621-631.

Pei SJ, Zhang G, Huai H. 2009. Application of traditional knowledge in forest management: ethnobotanical indicator of sustainable forest use. Forest Ecol Manag 257: 2017-2021.

Pei SJ. 2013. Ethnobotany and sustainable use of biodiversity. Plant Divers Res 35: 401-406.

Permana, EN, Gunawijaya J. 2011. Local-wisdom of disaster mitigation on Baduy. Jurnal Makara 15: 67-76. [Indonesian]

Rahmawaty, Samosir JB, Batubara R, Rauf A.. 2019. Diversity and distribution of medicinal plants in the Universitas Sumatera Utara Arboretum of Deli Serdang, North Sumatra, Indonesia. Biodiversitas 20: $1457-1465$.

Sartika W. 2013. Studi etnobotani keanekaragaman pangan Etnis Batak Toba di Kecamatan Baktiraja Kabupaten Humbang Hasundutan. Jurnal Pendidikan Ilmu-Ilmu Sosial 5: 20-25. [Indonesian] 
Simatupang W. 2018. Potensi pengembangan produk olahan pertanian untuk mendukung perkembangan pariwisata. Jurnal Muara Sains, Teknologi, Kedokteran dan Ilmu Kesehatan 2: 566-579. [Indonesian]

Steenberge DJ. 2016. Strategic customary village leadership in the context of marine conservation and development in Southeast Maluku, Indonesia. Human Ecol 44: 311-327.

Sukarata M. 1999. Pengenalan dan pemahaman local genius menghadapi era globalisasi Indonesia. Nirmana 1: 40-46. [Indonesian]

Supiandi MI, Leliavia, Syafruddin D, Utami YE, Sekunda R. 2019. Plant fruits used as food by the Dayak community of Tamambaloh in Labian Ira'ang Village, Kapuas Hulu District, Indonesia. Biodiversitas 20: 1827-1832.

Supiandi MI, Mahanal S, Zubaidah S, Julung H, Ege B. 2019. Ethnobotany of traditional medicinal plants used by Dayak Desa Community in Sintang, West Kalimantan, Indonesia. Biodiversitas 20: $1264-1270$

Suryadarma. 2008. Diktat kuliah etnobotani, Jurusan Pendidikan Biologi FMIPA, Universitas Negeri Yogyakarta, Yogyakarta.
Susanti R, Zuhud EAM. 2019. Traditional ecological knowledge and biodiversity conservation: the medicinal plants of the Dayak Krayan people in Kayan Mentarang National Park, Indonesia. Biodiversitas 20: $2764-2779$

UNESCO. 2009. Ekologi dan budaya Flores Barat. Sisipan national geographic Indonesia UHJAK/2009/PI/H/8.

Verheijen JAJ. 1982. Dictionary of Manggarai plant name. Department of Linguistics, The Australian National University, Canberra.

Walujo EB. 2011. Keanekaragaman hayati untuk pangan. Makalah disampaikan di Konggres Ilmu Pengetahuan Nasional X Jakarta 9-10 November. [Indonesian]

Walujo EB. 2011. Sumbangan ilmu etnobotani dalam memfasilitasi hubungan manusia dengan tumbuhan dan lingkungannya. Jurnal Biologi Indonesia 7: 375-391.

Wiryono, Wanandi Y, Ilahi AK, Deselina, Senoaji G, Siswahyono. 2019. The local knowledge of the plant names and uses by Semende tribe people in Kaur District, Bengkulu Province, Indonesia. Biodiversitas 20: 754-761. 